\title{
Susan Mann, The Talented Women of the Zhang
}

Family

Berkeley, Californie, University of California Press, 2007, xvi+322 p.

\section{Charlotte Furth}

\section{OpenEdition}

\section{Journals}

Electronic version

URL: http://journals.openedition.org/chinaperspectives/4752

DOI: $10.4000 /$ chinaperspectives. 4752

ISSN: 1996-4617

\section{Publisher}

Centre d'étude français sur la Chine contemporaine

Printed version

Date of publication: 1 December 2008

Number of pages: 102-104

ISSN: 2070-3449

\section{Electronic reference}

Charlotte Furth, "Susan Mann, The Talented Women of the Zhang Family », China Perspectives [Online], 2008/4 | 2008, Online since 01 December 2008, connection on 21 September 2020. URL http://journals.openedition.org/chinaperspectives/4752 ; DOI : https://doi.org/10.4000/ chinaperspectives. 4752

This text was automatically generated on 21 September 2020 .

(c) All rights reserved 


\title{
Susan Mann, The Talented Women of the Zhang Family
}

Berkeley, Californie, University of California Press, 2007, xvi+322 p.

\author{
Charlotte Furth
}

1 Susan Mann's pioneering book, Precious Records: Women in China's Long Eighteenth Century (Stanford University Press, 1997), was a breakthrough work by one of the late twentieth century's most accomplished social historians. It made upper-class women of the eighteenth century Jiangnan region of China visible, showed how gender can illuminate social change in law, culture, and economy, and argued powerfully that even while confined to the domestic "inner quarters," elite women like these could be agents of the Confucian patriarchal order, not just its victims. Central to Mann's narrative were the contradictions and ambiguities surrounding classical and literary "talent" in women - as reported in the writings of the scholarly men who were their kin, and as voiced by learned women themselves in the only literary form considered respectable for females, poetry. Although the book broke fresh ground in its use of women's poetry to capture personal life experience, the only individual woman whose portrait can easily be conjured up from the pages of Precious Records is Yun Zhu, the matriarchal compiler of a famous anthology of female poets published under the sponsorship of her son in 1831.

2 It is not surprising, then, that Mann has followed up Precious Records with a more intimate look at some of the personal lives that her earlier research encountered but could not unfold for her readers. Thumbing through Precious Records, one will find plenty of references to the prefecture of Changzhou, Yun Zhu's home district and a centre of female learning, but hardly any to the Zhang family of the same place. There is a passing sentence: "Zhang Qi's four daughters wrote countless poems to one another during the years when they were separated by marriage" (109). Another reference, a hundred pages later, refers to the same women as the "four nieces of Zhang Huiyuan [Zhang Qi's brother]... Each left a collection of works, including calligraphy, that was carefully preserved, with prefaces and memoirs, by their father and younger brother" (204). Neither of these gives any real clues to individual lives, or to the web of marriage 
and lineage ties among the Zhangs that supported a multigenerational network of female talent. To do so is the aspiration of this new book.

Mann organises her intimate narrative around three portraits: a mother, Tang Yaoqing (wife of Zhang Qi), her daughter Zhang Qieying, and her great-niece Wang Caipin (daughter of Qieying's sister). Although readers learn about more than a dozen lives, and are given a genealogical chart to keep track of them, at the heart of the story is Zhang Qieying and her three sisters and two brothers, who flourished from the 1790s until the 1860s, when the Taiping rebellion devastated their world. Along with her sisters, Qieying learned poetry from their mother and studied with her older brother until puberty mandated sex segregation; she experienced the death of that older brother two years later, and was herself wed at 22 in a marriage that her father arranged with one of his young literary protégés. However, it was agreed that she would remain in her parents' household until her scholar husband had succeeded in attaining rank and office, and two of her younger sisters were wed under similar uxorilocal arrangements, all of which stretched out over the years. As a result of the death of the oldest son Juesun in adolescence, the youngest child and only surviving male, Yuesun, became the Zhang heir, and this man who had been raised with four older sisters eventually became the formal head of household responsible for three of them, along with their husbands and children. Qieying's personal journey included the death from smallpox of her two infant children, travel with the family to accompany their father when he received an appointment as a county magistrate, and finally, in her forties, separation from her sisters and removal to Beijing, where her husband now ranked as a minister, and where she became well known among the female talents of the capital elite.

4 How did a life path like this foster female talent? In effect the four Zhang sisters flourished as poets due to their education by a learned mother, and due to the support of their male kin, who promoted the ci genre of "song lyric" at which they excelled, and made it a Changzhou literary specialty. Above all it was due to flexible kinship nodes that functioned around affinal relationships. As husbands and fathers followed the essentially itinerant pursuit of scholarship and office, employed far away as tutors and private secretaries if not as magistrates or ministers, the wives and children were left behind clustered in female-centred households where sororal ties were strong, and maternal uncles and brothers played an informal but important role.

5 Mann's problems with her material are the familiar ones for scholars exploring gender history in premodern China-dependence upon sources authored by males, usually kinsmen. Moreover, the poetical record left by women themselves, which has been opened up recently by scholars such as Kang-i Sun Chang, and in the case of the Zhang oeuvre has been lovingly translated here by Mann, turns out to expose a relatively narrow, if deep, range of emotions and experience. Mann, left with the persistent problem of a record heavy with silences, has taken advantage of recent experimental trends in literary biography to play with the boundaries of the historical form, imagining incidents and giving her heroines a subjective narrative voice. First, each biography is interlarded with imagined tableaux that Mann refers to as "setting the scene" (Prologue, xiv). A girl receives lessons in the Analects from her grandfather; a girl at her studies reflects on her observations of her parents' reactions to her older brother's death; sisters decide that their recently widowed brother needs a concubine; at a dinner table a magistrate tells his wife and daughters about the cases he is trying; a 
mother and daughter go on a journey to return a husband's body to his natal home for burial. We are offered the imagined text of letters presumed to pass between two sisters who are separated. To relate documentary evidence to incidents such as these, flagged as the author's invention, requires careful and occasionally frustrating attention to footnotes, while the very hybridity of genres makes the boundaries being blurred impossible to ignore.

6 Second, in addition to invented scenes depicting action, Mann has added an imagined personal voice, allowing her protagonists to express emotions directly. A young groom's shyness makes his bride "feel more confident" (16). She is "often bored" and "longs for home" (21). Another young woman is "exhausted and discouraged" by household chores that fall on her shoulders while her mother is grief-stricken (63). In the privacy of her bedroom a wife "weeps in frustration and anger" (91). With this kind of narrative voice Mann certainly "tells a good story" - as a back jacket blurb says and we can argue for trust in the historical instincts of a scholar who has been steeped for so many years in the archive of high Qing Chinese society. However I am not sure these imaginative exercises allow us to know the Zhang women better. The emotions evoked here tend towards the generic joys and sorrows of the Chinese woman's imagined life path, and don't capture any idiosyncrasies of personality- irony, humour, pride, ebullience, timidity, boldness, stubbornness - that might differentiate the Zhang women from one another as individuals. Yet these are what make a vivid character, whether in history, life, or fiction. For example, in the third generation, the adolescent Wang Caipin (Zhang Qieying's niece), together with her sisters and cousins, organised a poetry club plainly modelled on the "Crab Flower Club" in the eighteenthcentury novel Dream of the Red Chamber, but Mann's evocation of their gatherings, though deft, can't capture the vivacity of the fictional heroines or their world.

7 By offering readers an essentially modern and psychological novelistic voice, Mann's narrative style calls attention to some limitations of classical Chinese poetry when looked to for today's forms of subjective interiority. In the world of the Zhang women, poetry was occasional, social, and ephemeral, and the small amount that was published was selected by both its author and her kin. As Mann herself notes, a woman's poem that survives the filter of self-censorship and family expectations is hardly an expression of a writer's spontaneous feelings alone. The examples offered of poems by Zhang women follow rhetorical paths that are heartfelt and at the same time deeply traditional, the subtlety of their metrical forms and learned allusions bleached out in English translation. Difficult to grasp without specialised learning in the best of cases, they lose force when juxtaposed to the flatter, more familiar emotionality of the historical novelist genre. Only on rereading did I better appreciate Qieying's poem recalling the death of her two children (94), or the poems exchanged as commentary on a painting of three Zhang sisters and their husbands, "Linking Verses Across Adjoining Rooms" (96-99). These might be more compelling in a narrative that did not try to make the Zhang women's inner lives more like our own.

8 On the other hand, when Mann goes back to her established authorial persona of social historian (flagged as "The Historian Says" in homage to Sima Qian's classic), she makes a better case for the toughness, resilience, and savvy the Zhang women displayed in meeting the challenges of their lives. Reading between the lines of surviving (male) family memoirs, she suggests how they dealt with a mentally unstable chaste widow in the household; how they coped with the long stretches of male absence; how they 
sustained the ritual reputation of their families; how they managed - and earned money. Her conclusion is that in contrast with the eighteenth century, when the spectacle of female talent provoked controversy, by the nineteenth century no Jiangnan elites questioned the utility of education in women, who were recognised as essential to the survival of the culture of scholarship and who played a major role in masking its economic and social costs.

9 Mann's feminist agenda is to defend the traditional "talented woman" from twentiethcentury reformers and revolutionaries, who derided them as useless social parasites and their art as stale ornamentation. In some ways the story of the Zhang family women does this admirably, showing the training and responsibilities of traditional women that would make them well prepared to act as agents of change when the opportunity arose. On the other hand, there remains an eloquence in the silences of the record she has attempted to flesh out. Such silences hint that the stories historical actors allow themselves to tell are not only documentary straitjackets within which historians must move, but also the stuff of their imaginative worlds, binding them as well as history. Here we get a sense of the very real confinement of female energies that became available for release only with the avalanche of modernity. 